\title{
Morphological and Molecular Characterization of Alternaria Isolates Causing Purple Blotch Disease of Onion
}

\author{
B.S. Chethana ${ }^{1 *}$, Girija Ganeshan ${ }^{2}$, Archana S. Rao ${ }^{2}$ and K. Bellishree ${ }^{2}$ \\ ${ }^{1}$ AICRP, ZARS, VC Farm, Mandya, University of Agricultural Sciences, \\ Bangalore, Karnataka, India \\ ${ }^{2}$ Division of Plant Pathology, Indian Institute of Horticultural Research, Hessaraghatta Lake \\ PO, Bangalore, Karnataka, India \\ *Corresponding author
}

\section{A B S T R A C T}

Purple blotch is the most destructive disease commonly prevailing in almost all onion growing pockets except in very cool production areas of the world. The present study was

\begin{tabular}{|c|}
\hline Keywords \\
\hline $\begin{array}{l}\text { Onion, Purple blotch, } \\
\text { Alternaria, } \\
\text { Morphological, } \\
\text { Molecular } \\
\text { characterization, } \\
\text { Diversity }\end{array}$ \\
\hline Article Info \\
\hline $\begin{array}{l}\text { Accepted: } \\
28 \text { March } 2018 \\
\text { Available Online } \\
\text { 10 April } 2018\end{array}$ \\
\hline
\end{tabular}
carried out to understand the diversity in Alternaria population causing purple blotch disease of onion. Out of fifty six geographical Alternaria isolates of Karnataka seventeen were selected as descriptive isolates based on morphological characteristics for understanding the genetic variability. The isolates exhibited Ash, Ashy black, Ashy white, Ashy green and blackish green colour. Sabouraud dextrose agar supported the maximum growth whereas corn meal agar did not support the growth. Asthana Hawker's medium supported the sporulation of the isolates. The isolates showed variability in shape, conidia length, width, beak length and number of septa. Sequencing and blasting of nucleotide sequence of ITS region of ribosomal DNA of isolates revealed $100 \%$ matching with five different species of Alternaria viz., A. porri, A. alternata, A. tenuissima, A. palandui and A. brassicicola. Cluster analysis of ITS rDNA sequences did not provide reliable differentiation between the species and among the isolates. The results put forward that ITS region of ribosomal DNA is inappropriate for taxonomic resolution of Alternaria species infecting onion.

\section{Introduction}

Onion (Allium cepa L.) is a spice and vegetable crop of global importance. Onion is susceptible to numerous foliar, bulb and root pathogens that reduce yield and quality (Cramer, 2000). Excessive rains, humidity, temperature, pests and disease are critical factors of risk to onion cultivation. Irrespective of the varieties, the spectrum of diseases that affect onion remain the same.
Purple blotch of onion caused by $A$. porri (Ellis) Ciff. is one of the most serious disease in India (Gupta et al., 1986; Tripathi et al., 2008; Ramjegathesh et al., 2011). The yield losses of bulb and seed crop in India due to this disease under favourable conditions are upto 97\% (Gupta and Pathak, 1998; Lakra, 1999).

As a genus, Alternaria is a diverse and ubiquitous group of fungi having a high 
degree of variability in spore shape and size, pathogenicity and sporulation. To date classification and identification of Alternaria species is based primarily on the morphology and development of conidia and conidiophores, to a lesser degree on host plant association and colony morphology (Elliot, 1917; Wiltshire, 1947; Simmons, 1967). Several taxonomists have deliberations on whether morphological characters should be used as the sole criteria for delimiting species, especially regarding small-spored catenulate Alternaria species (Rotem, 1994; Kusabaand Tsuge, 1995; Andersen et al., 2001; Peever et al., 2004). These debates are based on the presence of considerable variability in conidium size, shape, and septation within each species as well as within a single Alternaria colony (Simmons, 1992). Furthermore conidial characteristics often overlap between closely related species, hindering the establishment of distinct and unambiguous species boundaries. To overcome the limitations of morphological markers, molecular markers (RAPD and RFLP) have been applied in systematic studies of Alternaria species.

Recent DNA marker technologies have revolutionized the plant pathogen genomic analysis and have been extensively employed in the identification, early detection and understanding genetic diversity of plant pathogen. Among the different DNA marker techniques, Internal Transcribed Spacer (ITS) regions of fungal DNA (rDNA) are identified as suitable targets for the analysis of fungal communities (White et al., 1990; Peay et al., 2008). The ITS region is the most widely sequenced DNA region in fungi useful for molecular systematics and is of great importance in distinguishing fungal species by PCR analysis (Martin and Rygiewicz 2005). Various researchers have reported different species of Alternaria causing purple blotch disease of onion in India. Osiru (2008) described the presence of Alternaria species is influenced by a number of factors such as climatic conditions, host crops and management conditions. The influence of climatic and management factors on the prevalence of species shows the presence of pathogen diversity. The pathogen population with a high pathogenic diversity poses difficulties in deploying stable resistant varieties, as these succumb to newly evolving pathogenic races or new species of Alternaria causing infection in onion crop. Considerable attention has been given for studying the diversity of Alternaria all over the world. Although India is the largest producer of onion in the world, limited importance is given to study the pathogen diversity and its geographical distribution despite the magnitude of damage caused by this pathogen incurring huge economic losses in terms of poor quality bulbs and low yields. Thus the present study was conducted to understand the pathogen causing purple blotch disease through morphology and molecular characterization

\section{Materials and Methods}

Collection, isolation, identification and maintenance of isolates

In the present investigation a survey was conducted during Kharif 2011 in eleven districts of Karnataka (Bangalore, Kolar, Tumkur, Raichur, Bijapur, Bidar, Gulbarga, Dharwad, Gadag, Belgaum and Shimoga) for the collection of purple blotch disease infected samples of onion field (Table 1). Onion leaves showing typical symptoms of purple blotch disease were collected and the pathogen was isolated within $24 \mathrm{~h}$ following standard tissue isolation. The cultures were purified by single spore isolation using water agar and potato dextrose agar. The purified culture were maintained on PDA slants at $5^{\circ} \mathrm{C}$ under refrigeration and renewed once in 30days. 


\section{Cultural and Morphological characterization}

Cultural characteristics of all the isolates were studied on PDA medium. A culture disc of $5 \mathrm{~mm}$ diameter was cut using cork borer from the peripheral region of the seven day old culture. The disc was placed at the center of the PDA plate and incubated at $27 \pm 1^{\circ} \mathrm{C}$ for 15 days. For each isolate four replications were maintained. Colony diameter was measured on the $7^{\text {th }}$ day after inoculation. Observations on cultural characters viz., colony growth, colour of mycelium, growth pattern, zonation, sectors, margin growth and colour of colony on reverse side of the culture plate were recorded.

Observations on sporulation characters were recorded after 15 days of inoculation. To assess the conidia count in each of the isolate conidial suspension was prepared by adding $10 \mathrm{ml}$ of sterile distilled water to each of the culture plates. The conidial suspension was serially diluted and conidial concentration (conidia/ml) was determined using a Neubauer Heamocytometer.

Variability among the cultures isolated was studied on synthetic (Sabourauds Dextrose Agar, Richards Agar and Asthana and Hawker's Agar) and non-synthetic media (Oat Meal Agar, Corn Meal Agar, Bean Extract Agar, Host Extract Agar, Malt Extract Agar, Potato Carrot Agar and Potato Dextrose Agar). Three replicates were maintained for each media. The composition and preparation of the following media were obtained from "Ainsworth and Bisby's Dictionary of the fungi" (Ainsworth, 1961) and "Plant Pathological methods, fungi and bacteria" (Tuite, 1969) excepting host leaf extract agar medium.

\section{Conidial characterization}

The cultures obtained from single spore isolation were grown on PDA medium at $27 \pm 1^{\circ} \mathrm{C}$ for ten days. The culture was observed for sporulation upto 15 days after inoculation. The cultures which were not sporulated were inoculated on the onion leaves or inflorescence stalk by detached leaf method and observed for sporulation. The conidial characteristics viz., colour, shape, size, number of transverse and longitudinal septa and length of the beak were recorded in fifty conidia selected randomly from different microscopic fields of Carl Zeiss bright field microscope under 20X magnification. The average of fifty observations was taken for each parameter using the formula given below.

Average $/$ mean $=\frac{\text { Sum of all the observations }}{\text { total number of observation taken }}$

\section{Molecular characterization}

\section{Extraction of genomic DNA, amplification and phylogenetic analysis}

DNA extraction was done from the mycelia obtained from 7 day old still potato dextrose broth cultures of Alternaria isolates incubated at $27 \pm 1^{\circ} \mathrm{C}$. Mycelium was harvested from the liquid broth by filtration through Whatman No.1 filter paper, blot dried and subsequently dried to a fine powder in liquid nitrogen. The mycelial biomass was quick frozen in liquid nitrogen and ground into fine powder.

DNA was extracted from the frozen mycelial powder employing a slightly modified method of Raeder and Broda (1985).by incubating $37^{\circ} \mathrm{C}$ for $10 \mathrm{~min}$ after the phenol: chloroform: isoamyl alcohol (25:24:1) precipitation. This was followed by precipitation with 0.54 volumes of isoamyl alcohol.

The ITS region of rDNA of the fungal isolates were amplified by PCR with universal primer pairs (White et al., 1990). PCR reaction (50 $\mu \mathrm{l})$ were performed with primer ITS1(Gardes 
and Burns, 1993) and ITS4 (White et al., 1990) in an Eppendorf master cycler by 40 cycles of denaturation at $94^{\circ} \mathrm{C}$ for $30 \mathrm{~s}$, annealing at $53^{\circ} \mathrm{C}$ for $40 \mathrm{~s}$ and extension at $72^{\circ} \mathrm{C}$ for $45 \mathrm{~s}$ with an initial denaturation of 5 min at $94^{\circ} \mathrm{C}$ and final extension of $10 \mathrm{~min}$ at $72^{\circ} \mathrm{C}$ after cycling. Amplified PCR products were separated in $1 \%$ agarose gel in TrisBorate -EDTA (TBE) buffer Ethidium bromide was added to the agarose gel at 0.5 $\mu \mathrm{g} / \mathrm{ml}$.

The gel is visualized by trans-illuminator in Gel doc unit with image capture system and photographed. Primers and all the reagents used in this study were procured from Fermentas life sciences, Bangalore. The amplified ITS region of rDNA products with primer pair(ITS1 and ITS4) using QIA quick PCR Purification Kit (Qiagen Inc., Mississauga, Ontario) yielded $560 \mathrm{bp}$. The purified product (20ng) was sent for sequencing. Sequencing of the purified product of PCR was done using the BigDye Terminator Cycle Sequencing system (Applied Bio systems) USA and analysed with ABI 3100 analyzer capillary machines. Sequencing of the PCR product was performed in both directions. Nucleotide homology searches were performed with the nucleotide program BLAST (http://ncbi.nlm.nih.gov/) confirm the identity of the pathogen.

\section{Data analysis}

A multiple-sequence alignment was performed with similar reference sequences of other Alternaria isolates available in the NCBI database using Molecular Evolutionary Genetic Analysis (MEGA 4) software and a BLAST similarity test was performed. The regions of the ambiguity and positions that were not available for all the sequences compared were omitted, Phylogenetic analysis were constructed from the aligned sequences using MEGA.

\section{Results and Discussion}

Fifty six geographical isolates of Alternaria spp. collected from eleven districts of Karnataka showed variation in morphological and cultural characteristics. Out of these isolates seventeen isolates were selected as descriptive isolates for understanding the genetic variability of the pathogen by morphological and molecular criteria. On potato dextrose medium the isolates showed significant variation in cultural characters viz., colony colour, growth pattern, margin and colony colour on the reverse side of the plate. The isolates were characterized by regular, irregular, circular, smooth and rough colonies and did not produce any diffusible pigments which resulted in change of colour of the medium. However zonation or sectoring was absent in all the isolates. Based on colony colour isolates were classified into five groups viz., ash, ashy black, ashy green, ashy white and blackish green (Table 1). The results of colony colour revealed variability among the isolates which are in accordance with the reports of Pryor and Michailides (2002) who categorized isolates of Alternaria infecting pistachio into four groups. Similarly Prasad et al., 2009 grouped the A. helianthi isolates into four groups. Chowdappa et al., (2012) working on diversity analysis of $A$. porri described the colour of the colonies on PDA medium were either greyish orange or brownish orange in color having cottony texture showing dark orange colour on the reverse side of the plate. Several workers have noticed the diversity in colony color, margin and topography among the isolates of $A$. solani (Kaul and Saxena, 1988; Perez and Martinez, 1996 and Babu et al., 2000).

All the isolates exhibited substantial variation in the mycelial growth rate on potato dextrose agar. Based on colony diameter/ growth rate, the isolates were classified into seven groups. Among the isolates the fastest colony growth was recorded in the isolate OLHi1-3 whereas 
the isolate OLPk recorded the slowest colony growth (Table 2). Based on sporulation habit isolates were classified into three groups.

Extending studies on cultural variability, the Alternaria isolates were characterized on different synthetic and non-synthetic media. The isolates showed varied growth with varying margin type, colony colour and colour of the colony reverse. Likewise Goyal et al., (2011) observed extensive variation in mycelial growth and sporulation among the isolates of A. brassicae. Supporting variation in mycelial growth rate Chowdappa et al., 2012a classified the isolates of $A$. porri into fast, intermediate and slow growing groups. Observations on variation in cultural characteristics of Alternaria isolates on different media are in line with Ramjegathesh and Ebenezar (2012). Among the media evaluated Sabourauds dextrose agar, potato dextrose agar and oat meal agar has supported maximum growth of the fungus (Table 3). Naik et al., (2010) reported Sabourauds dextrose agar as the best medium supporting the growth of A. solani. Mohan (1996) and Karthikeyan (1999) reported potato dextrose agar as the best medium for the growth of $A$. palandui causing leaf blight of onion. Results on oat meal agar medium supporting the growth of $A$. palandui and $A$. alternata are in line with the findings of Kannan (1992). Alternaria isolates showing slow growth in corn meal agar, potato carrot agar and Richard's agar may be due to the availability of poor quality sugars present in these medium (Karlatti, 1983; Prasad, 2002 and Savitha, 2004).

Variation in sporulation was observed among the isolates on different culture media. All the isolates showed maximum sporulation on Asthana Hawker's medium followed by potato dextrose agar. Meena et al., 2012 have reported good sporulation of all the isolates of A. brassicae in Asthana and Hawker's medium.
In the present study, spore size and shape of conidia were used for identifying the fungus (Fig. 1). The average conidial length of the isolates ranged between 17.90 to $76.15 \mu \mathrm{m}$ however, longest conidial length was recorded in OLNau $(76.15 \mu \mathrm{m})$ (Table 4) followed by OLA1 $(70.99 \mu \mathrm{m})$ and shortest in OLTor $(17.90 \mu \mathrm{m})$. The average conidial width among different isolates varied from 6.24 to 25.38 $\mu \mathrm{m}$, and was observed to be highest in OLA1 $(25.38 \mu \mathrm{m})$ followed by OLNau $(23.82 \mu \mathrm{m})$ and lowest in OLTor $(6.24 \mu \mathrm{m})$. All the isolates produced beaked conidia. The beak length varied from 3.31 to $55.48 \mu \mathrm{m}$. The isolate OLA1 had the longest beak $(55.48 \mu \mathrm{m})$ followed by OLShi $(14.40 \mu \mathrm{m})$, while it was short in OLTor $(3.65 \mu \mathrm{m})$, OLPk $(3.88 \mu \mathrm{m})$ and OLHbg $(3.31 \mu \mathrm{m})$.

The isolates i.e. OLMb, OLNau, OLLin, OLSik, OLAnn, OLShi, OLHi1-3and OLHi14 produced medium beak while the isolates OLWg, OLD1, OLTor, OLNg, OLHbg, OLPk, OLCb and OLSo produced small beak. The average number of transverse septa, varied from 3 to 8 , highest being observed in OLA1 and lowest is in OLTor. The number of longitudinal septa varied from 1 to 3 , highest was noticed in OLA1 and most of the isolates showed at least one longitudinal septa. The spores of isolates OLA1 and OLNau have been identified as bigger spores with 7-8 septa in conidum.

The isolates i.e. OLMb, OLLin, OLD1, OLShi, OLAnn, OLHi1-3, OLHi1-4 and OlCb produced medium spore with 5-6 septa. The isolates OlWg, OLTor, OLSik, OINg, OLHbg, OlPk and OlSo produced small spores with 34 septa in conidium. The characteristics of the Alternaria isolates in question were compared with Alternaria species already reported on the host. The variation in conidial size was significant among the isolates of Alternaria infecting onion. 
Table.1 Cultural characteristics of Alternaria isolates infecting onion crop

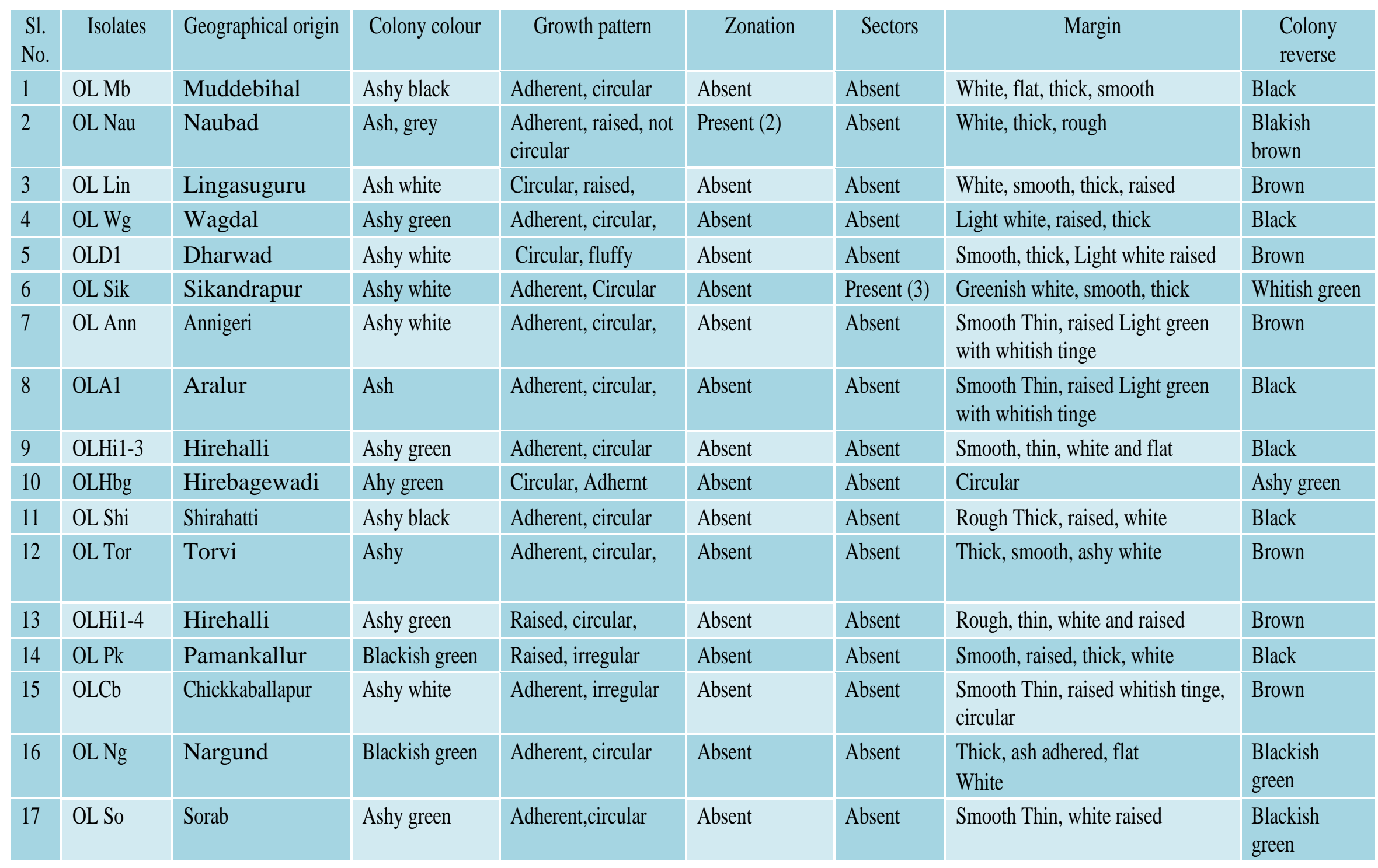


Table. 2 Colony diameter and sporulation behaviour of Alternaria isolates of onion

\begin{tabular}{|l|c|c|c|c|}
\hline Isolates & $\begin{array}{c}\text { Colony diameter } \\
(\mathbf{m m}) \begin{array}{c}\text { after 7 days of } \\
\text { inoculation }\end{array}\end{array}$ & $\begin{array}{c}\text { Colony } \\
\text { growth rate } \\
(\mathbf{m m} / \mathbf{d a y})\end{array}$ & Sporulation & Conidia/ml \\
\hline OL Mb & 65 & 9.29 & +++ & $6 \times 10^{5} / \mathrm{ml}$ \\
\hline OL Nau & 62 & 8.86 & + & $0.5 \times 10^{5} / \mathrm{ml}$ \\
\hline OL Li & 50 & 7.14 & + & $0.3 \times 10^{5} / \mathrm{ml}$ \\
\hline OL Wg & 45 & 6.43 & ++ & $3 \times 10^{5} / \mathrm{ml}$ \\
\hline OLD1 & 67 & 9.57 & ++ & $3 \times 10^{5} / \mathrm{ml}$ \\
\hline OL Sik & 66 & 9.43 & +++ & $7 \times 10^{5} / \mathrm{ml}$ \\
\hline OL Ann & 50 & 7.14 & ++ & $2.5 \times 10^{5} / \mathrm{ml}$ \\
\hline OLA1 & 68 & 9.71 & +++ & $5 \times 10^{5} / \mathrm{ml}$ \\
\hline OLHi1-3 & 65 & 8.29 & ++ & $3.5 \times 10^{5} / \mathrm{ml}$ \\
\hline OL Hbg & 60 & 8.14 & +++ & $8 \times 10^{5} / \mathrm{ml}$ \\
\hline OL Shi & 57 & 9.29 & ++ & $2.0 \times 10^{5} / \mathrm{ml}$ \\
\hline OL Tor & 65 & 10.00 & + & $0.5 \times 10^{4} / \mathrm{ml}$ \\
\hline OLHi1-4 & 70 & 5.00 & ++ & $2.5 \times 10^{5} / \mathrm{ml}$ \\
\hline OL Pk & 35 & 7.14 & ++ & $0.5 \times 10^{5} / \mathrm{ml}$ \\
\hline OL Cb & 50 & 8.57 & +++ & $6 \times 10^{5} / \mathrm{ml}$ \\
\hline OL Ng & 60 & 8.29 & ++ & $4.5 \times 10^{5} / \mathrm{ml}$ \\
\hline OL So & 58 & & + & \\
\hline
\end{tabular}


Table.3 Effect of different media on the mycelial growth of Alternaria isolates

\begin{tabular}{|c|c|c|c|c|c|c|c|c|c|c|c|}
\hline Isolates & & & & Colony c & imeter 0 & lifferen & nedia(m & & & & Mean \\
\hline Media & SDA & RA & AHA & OMA & CMA & BEA & HEA & MEA & PCA & PDA & \\
\hline OL Mb & 70.00 & 70.00 & 55.00 & 85.00 & 37.50 & 74.00 & 65.00 & 68.00 & 68.00 & 80.00 & 67.25 \\
\hline OL Nau & 73.50 & 52.00 & 55.00 & 77.50 & 60.00 & 80.00 & 72.00 & 77.50 & 60.00 & 72.00 & 67.95 \\
\hline OL Lin & 78.50 & 85.00 & 80.00 & 85.00 & 52.00 & 80.00 & 72.5 & 70.00 & 70.00 & 80.00 & 75.30 \\
\hline OL Wg & 74.30 & 66.00 & 82.00 & 70.00 & 40.00 & 76.00 & 75.00 & 50.00 & 70.00 & 61.00 & 66.43 \\
\hline OLD1 & 77.00 & 63.00 & 57.50 & 81.50 & 42.50 & 83.50 & 75.00 & 53.00 & 56.50 & 80.00 & 66.95 \\
\hline OL Sik & 85.00 & 40.00 & 80.00 & 68.00 & 42.00 & 85.00 & 80.00 & 63.00 & 60.00 & 46.00 & 64.90 \\
\hline OL Ann & 85.00 & 80.00 & 85.00 & 85.00 & 40.00 & 85.0 & 80.00 & 55.00 & 70.00 & 85.00 & 75.00 \\
\hline OLA1 & 79.50 & 75.00 & 70.00 & 85.00 & 45.00 & 70.00 & 70.00 & 64.00 & 58.00 & 85.00 & 70.15 \\
\hline OLHi1-3 & 80.00 & 80.00 & 70.00 & 80.00 & 65.00 & 22.00 & 62.00 & 60.00 & 50.00 & 80.00 & 64.90 \\
\hline OL Hbg & 80.00 & 50.00 & 72.00 & 85.00 & 50.00 & 65.00 & 75.00 & 84.00 & 70.00 & 85.00 & 71.60 \\
\hline OL Shi & 70.00 & 60.00 & 62.00 & 85.00 & 65.00 & 75.00 & 68.00 & 70.00 & 57.00 & 80.00 & 69.20 \\
\hline OL Tor & 80.00 & 58.00 & 72.50 & 68.50 & 40.00 & 82.00 & 75.00 & 56.00 & 57.50 & 81.00 & 67.05 \\
\hline OL Hi1-4 & 85.00 & 85.00 & 80.00 & 50.00 & 60.00 & 80.00 & 75.00 & 83.00 & 65.00 & 80.50 & 74.35 \\
\hline OL Pk & 78.5 & 75.00 & 70.00 & 80.00 & 52.00 & 60.00 & 72.5 & 45.00 & 50.00 & 80.00 & 66.30 \\
\hline OLCb & 80.00 & 65.00 & 75.00 & 78.00 & 55.00 & 63.00 & 70.00 & 75.00 & 45.00 & 79.00 & 68.50 \\
\hline OL Ng & 85.00 & 55.00 & 85.00 & 88.00 & 40.00 & 80.00 & 80.00 & 85.00 & 77.50 & 85.00 & 76.05 \\
\hline OL So & 80.00 & 70.00 & 72.00 & 85.00 & 55.00 & 75.00 & 80.00 & 85.00 & 65.00 & 80.50 & 74.75 \\
\hline Avg mean & 78.90 & 66.41 & 71.94 & 78.62 & 49.47 & 72.68 & 73.35 & 67.26 & 61.74 & 77.65 & \\
\hline
\end{tabular}


Table.4 Variation in conidial morphology of Alternaria isolates of onion

\begin{tabular}{|c|c|c|c|c|c|c|c|c|c|c|c|}
\hline \multirow{4}{*}{$\begin{array}{l}\text { Sl. } \\
\text { No. } \\
1\end{array}$} & \multirow{4}{*}{$\begin{array}{l}\text { Onion } \\
\text { isolates } \\
\text { OL Mb }\end{array}$} & \multirow[t]{3}{*}{ Colour } & \multirow[t]{3}{*}{ Surface } & \multirow[t]{3}{*}{ Shape } & \multirow[t]{3}{*}{ Beak } & \multirow{2}{*}{\multicolumn{2}{|c|}{$\begin{array}{c}\text { No of septa (Transverse } \\
\text { Longitudinal) }\end{array}$}} & \multicolumn{2}{|c|}{ Conidia } & \multicolumn{2}{|c|}{ Beak } \\
\hline & & & & & & & & Length & width & Length & Thickness \\
\hline & & & & & & $\mathbf{T}$ & $\mathbf{L}$ & \multicolumn{2}{|c|}{ Mean $(\boldsymbol{\mu m})$} & \multicolumn{2}{|c|}{$(\mu \mathrm{m})$} \\
\hline & & Dark brown & Smooth & Obclavate & Medium & $5-6$ & 1 & 30.51 & 10.55 & 11.71 & 3.89 \\
\hline 2 & OL Nau & Chocolate brown & Smooth & Obclavate & Medium & 7 & 1 & 76.15 & 23.82 & 10.53 & 8.65 \\
\hline 3 & OL Lin & Golden brown & Smooth & Obclavate & Medium & 6 & 2 & 45.10 & 13.70 & 10.80 & 3.81 \\
\hline 4 & OL Wg & Dark brown & smooth & Ovate & Short & 4 & 1 & 27.95 & 10.39 & 6.21 & 3.23 \\
\hline 5 & OLD1 & Golden brown & Smooth & Obclavate & Short & 6 & 1 & 36.04 & 13.24 & 8.27 & 3.85 \\
\hline 6 & OL Sik & Golden brown & Smooth & Obclavate & Medium & 6 & 1 & 57.48 & 19.47 & 13.32 & 9.15 \\
\hline 7 & OL Ann & Dark brown & Smooth & Obclavate & Medium & 6 & 1 & 46.53 & 13.44 & 11.32 & 4.5 \\
\hline 8 & OLA1 & Golden brown & Smooth & Obpyriform & Long & $7-8$ & 3 & 70.99 & 25.38 & 55.48 & 7.51 \\
\hline 9 & OL Hi1-3 & Light brown & Smooth & Obclavate & Medium & $5-6$ & 1 & 28.49 & 10.50 & 10.06 & 3.81 \\
\hline 10 & OL Hbg & Light brown & Smooth & Obclavate & Short & 4 & $0-1$ & 24.21 & 9.86 & 3.31 & 3.18 \\
\hline 11 & OL Shi & Golden brown & Smooth & Obpyriform & Medium & 5 & $1-2$ & 29 & 9.74 & 14.4 & 4.68 \\
\hline 12 & OL Tor & Brown & Rough & Ovate & Short and blunt & 3 & 2 & 17.9 & 6.24 & 3.65 & 3.60 \\
\hline 13 & OL Hi1-4 & Light brown & Smooth & Obclavate & Medium & 6 & 1 & 26.89 & 9.50 & 11.06 & 4.51 \\
\hline 14 & OL Pk & Golden brown & Smooth & Ovate & Short & 4 & 2 & 35.98 & 11.04 & 3.88 & 3.84 \\
\hline 15 & $\mathrm{OL} \mathrm{Cb}$ & Light brown & Smooth & Obclavate & Medium & 5 & 1 & 29.28 & 7.81 & 10 & 4.82 \\
\hline 16 & $\mathrm{OL} \mathrm{Ng}$ & Light brown & Smooth & Obclavate & Short & 4 & 1 & 22.85 & 7.25 & 4.76 & 4.41 \\
\hline 17 & OL So & Golden brown & Smooth & Obpyriform & Medium & 4 & 1 & 34.07 & 9.69 & 7.16 & 4.55 \\
\hline
\end{tabular}


Table.5 Details of the species identification of Alternaria isolates based on ITS rDNA

\begin{tabular}{|c|c|c|c|c|c|}
\hline SI. No. & Isolates code & Place of collection & No. bases & Gene bank Accession number & Species identified \\
\hline 1 & $\mathrm{OL} \mathrm{Mb}$ & Muddebihal, Vijayapura & 509 & JX294489 & A. porri \\
\hline 2 & OLNau & Naubad, Bidar & 467 & JX294490 & A.alternata \\
\hline 3 & OL Lin & Lingasagur, Raichur & 485 & KC357742 & A.tenuissima \\
\hline 4 & OL Wg & Wagdal, Kalaburgi & 455 & JX666590 & A.porri \\
\hline 5 & OLD1 & Dharwad, Dharwad & 507 & JX666601 & A.palundi \\
\hline 6 & OL Sik & Sikandrapur, Bidar & 505 & JX666589 & A.tenuissima \\
\hline 7 & OL Anni & Annigere, Gadag & 505 & KC357739 & A.alternata \\
\hline 8 & OLA1 & Aralur, Kolar & 508 & JX666599 & A.porri \\
\hline 9 & OL Hi1-3 & Hirehalli, Tumakuru & 498 & JX666597 & A.alternata \\
\hline 10 & OL Hbg & Hirebagewadi, Belagavi & 509 & JX666591 & A.brassicicola \\
\hline 11 & OL Shi & Shirahatti, Dharwad & 505 & JX666592 & A.porri \\
\hline 12 & OL Tor & Torvi, Kalaburgi & 505 & JX666593 & A.porri \\
\hline 13 & OL Hi1-4 & Hirehalli, Tumakuru & 509 & JX666600 & A.alternata \\
\hline 14 & OL Pk & Pamankallur, Raichur & 501 & JX294491 & A.alternata \\
\hline 15 & $\mathrm{OL} \mathrm{Cb}$ & Chickkaballapur & 508 & KC357741 & Alternaria spp. \\
\hline 16 & OL Ng & Nargund, Dharwad & 509 & JX666594 & A.tenuissima \\
\hline 17 & OL So & Soraba, Shivamogga & 505 & KC357740 & A.alternata \\
\hline
\end{tabular}


Fig.1 Conidial morphology of Alternaria isolates causing purple blotch of onion
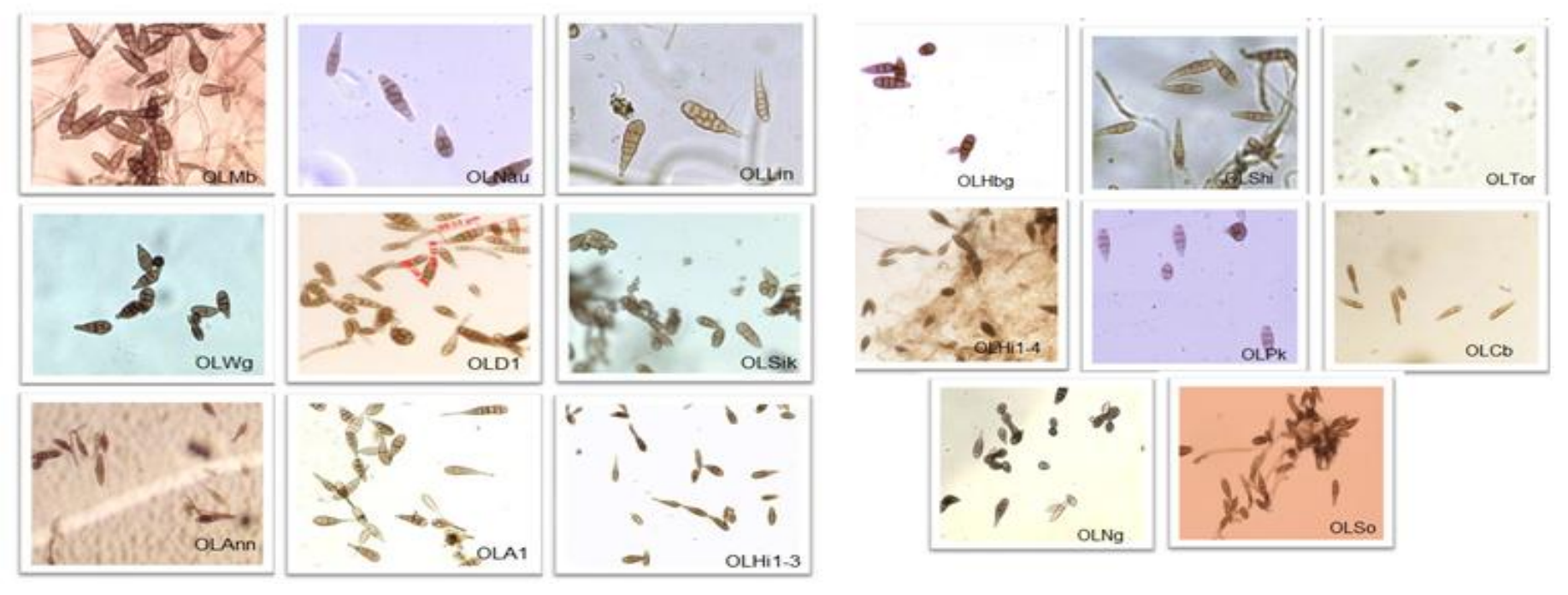

Fig.2 Phylogenitic analysis of Alternaria isolates of onion

Phylogenitic analysis of Alternaria isolates using ITS rDNA

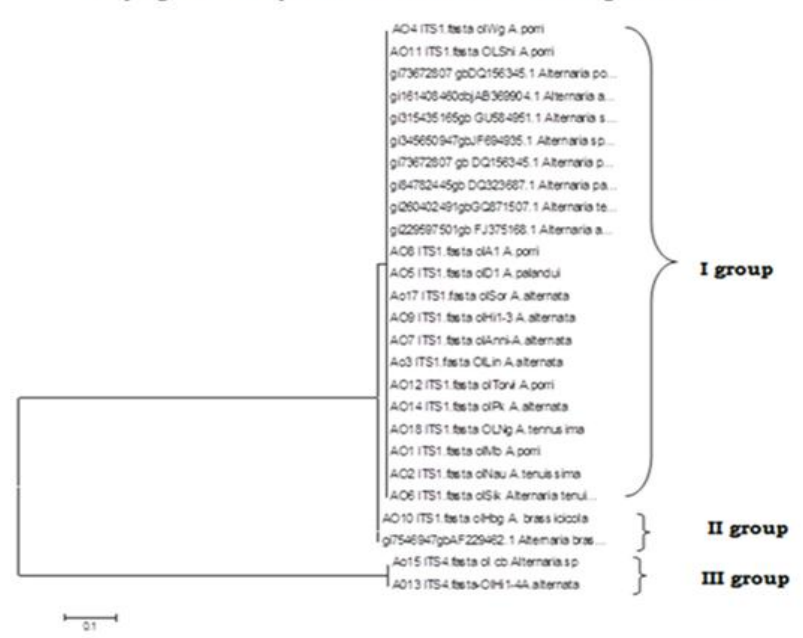


All the isolates produced conidia of smooth surface, golden brown to dark brown and obclavate shaped conidia measuring about 17.9-76.15 $\mu \mathrm{m} \times 7.25-25.32 \mu \mathrm{m}$ and beak length of 5.65-13.32 $\mu \mathrm{m} \times 2.51-9.15 \mu \mathrm{m}$ with 3-8 transverse septa and 1-3 longitudinal septa. In the present investigation, all the isolates showed variation in cultural characteristics which is not adequate to claim the existence of races of Alternaria species. Discussing the cultural variability Rotem, 1994 admitted many Alternaria species differ in cultural characteristics and acknowledged that if these characteristics suffice for identification of races then the number of races may be almost as big as the number of isolates being tested.

The conidial characters of the isolates are in accordance with those described by Ellis, 1971. However, Nolla (1927) reported the dimension of conidia as 105-220 $\mu \mathrm{m}-17.5-26$ $\mu \mathrm{m}$ in $A$. porri (Nolla, 1927), 10.26-77.52 $\mu \mathrm{m}$ $\times 4.56-14.82 \mu \mathrm{m}$ in A. alternata (Neergaard, 1945; Abubakar and Ado, 2009), 22-95 $\mathrm{m} \times$ 8-19 $\mu \mathrm{m}$ in A. tenuissima (Wiltshire, 1933), 10.5-77 $\times 3.5-14 \mu \mathrm{m}$ in $A$. palandui (Ayyangar, 1928), 38-146 × 10-73 $\mu \mathrm{m}$ in $A$. cepulae (Ponnappa, 1974), 18-130 × 8-30 $\mu \mathrm{m}$ in A. brassicola (Ellis, 1971). The conidial dimensions and colour of Alternaria isolates of onion collected from different localities of Karnataka were within the range of morphological explanation of the earlier recognized species. The conidial dimension of the isolates matched with $A$. alternata, $A$. tenuissima, A. palandui, A. cepulae and $A$. brassisicola. Similar results on variation in conidial size in the isolates of A. solani were reported by Rotem (1994), Varma et al., (2007). The results on morphological variability of isolate are in agreement with earlier workers (Meena et al., 2005; Kaur et al., 2007; Singh et al., 2007) who observed variability in different geographical isolates within Alternaria species.

\section{Molecular characterization}

Molecular characterization of geographical isolates was carried out based on the sequence of ITS region of rDNA. Sequencing and blasting of ITS rDNA of isolates revealed matching of five different species of Alternaria viz., A. porri, A. alternata, A. tenuissima, A. palandui and A. brassicicola. Cluster analysis of ITS rDNA sequences did not provide reliable differentiation between the species and among the isolates thus suggested the region of ribosomal DNA gene is inappropriate for taxonomic resolution of Alternaria species infecting onion. Correlation was not observed among the group of isolates based on conidial morphology, cultural characteristics, pathogenicity and nucleotide sequence of ITS region of rDNA.

It is evident from the ITS rDNA sequences that A. alternata and A. porri are the most prevalent species infecting onion in Karnataka. The ITS rDNA sequences of the isolates were submitted to the gene bank and the accession numbers obtained are listed in Table 5. Multiple sequence alignment of the isolates and of the matching species is given in Figure 2. Pryor and Michailides (2002) used ITS rDNA for the identification of Alternaria Isolates associated with Alternaria blight of pistachio. Correspondingly Chowdappa et al., (2012) analysed genetic variability in the isolates of $A$. porri on the basis of ITS sequences of rDNA. Similarly, Fernandez and Vargas (2007) identified 34 selected morphotypes among the isolates of Alternaria spp. Occurring on onion foliage belonging to $A$. destruens, A. tenuissima, $A$. palaundi and $A$. porri species group, based on internal transcribed spacer (ITS) region. The sequence data of the total size of the ITS1 and ITS2 regions, of the isolates including the 5.8SrDNA gene, of the isolates studied ranged from 455 to 509 . The results inferred 
that, the sequence of ITS region varied among the Alternaria isolates. The results of the present study are in agreement with the previous reports which showed that the ITS region vary among the species within a genus or among populations (Gardes et al., 1991).

\section{Phylogenetic analysis}

Phylogenetic analysis of ITS rDNA sequences executed by neighbour-joining method grouped the isolates into three clades (Fig. 2). The first clade consists of 14 isolates viz., OLWg, OLD1, OLSo, OLHi1-3, OLAnni, OLLin, OLSik, OLNau, OLPk, OLNg, OLMb, OLShi, OLA1 and OLTor. Only one isolate OLHbg was found under second clade. The third clade consists of two isolates OLCb and OLHi1-4. The Alternaria isolates clustered in clade I included five reference isolates from GenBank; AB087220 (A. porri), AB369904 (A. alternata), DQ323687 (A. palandui), GQ871507 (A. tenuissima) and JF694935 (Alternaria spp.). Clade II included only one reference isolate from the gene bank with Accession no AY154707 (A. brassicicola). Clade III included two reference isolates from GenBank FJ375168 (A. alternata) and GU584951 (Alternaria sp). The species $A$. alternata, $A$. palandui, $A$. porri and $A$. tenuissima were placed in monophyletic clade, whereas the species A. brassicicola and Alternaria sp. were placed separately in two clades. The clustering of isolates based on geographical origin was not evident. Clustering of isolates based on sequence of ITS rDNA did not provide reliable differentiation between the species and also among the isolates. Considering the improper differentiation between the species it is suggested that ITS region is inappropriate for taxonomic resolution of Alternaria species infecting onion.

Cluster analysis of the isolates is in agreement with Fernandez and Vargas (2007) in deriving phylogenetic relationship among the Alternaria isolates of onion based on ITS sequences of rDNA. They suggested that rDNA were not sufficient to differentiate Alternaria species infecting onion. Kadam et al., (2009) targeted the internal transcribed spacer (ITS) sequences within the ribosomal DNA (rDNA) region to delineate genetic variability among eight Alternaria species causing diseases in other crops and inferred that divergent sequences within the ITS regions can be employed to design species-specific PCR primer for use in molecular diagnostics.

The Alternaria isolates of onion were studied to understand their morphological and molecular diversity. The isolates exhibited variation among the isolates in colour and texture of the colony. Sabouraud dextrose agar supported the maximum growth and corn meal agar did not support the growth. Asthana Hawker's medium supported the sporulation. On PDA medium, the isolates showed significant difference pertaining to mycelial growth and sporulation. Variation in conidia shape, conidia length, width, beak length and number of septa was prominent among the isolates. Sequencing and blasting of nucleotide sequence of ITS region of ribosomal DNA of isolates revealed $100 \%$ matching with five different species of Alternaria viz., $A$. porri, A. alternata, A. tenuissima, $A$. zpalanduiand A. brassicicola. Cluster analysis of ITS rDNA sequences did not provide reliable differentiation between the species and among the isolates. The results put forward that ITS region of ribosomal DNA is inappropriate for taxonomic resolution of Alternaria species infecting onion.

\section{Acknowledgement}

The authors are very thankful to the director, Indian Institute of Horticultural Research, Bangalore for providing facilities to carry out the research work.

\section{References}

Abubakar, L., Ado, S.G., 2009. Genotype x environment interaction for resistance to purple blotch (Alternaria porri L. (Ellis) Cif.) in onion (Allium cepa L.) in Nigeria. Asian journal of crop science 1(1):15-25. 
Ainsworth, G.C., 1961. Dictionary of fungi by Ainsworth and Bisby's. Commonwealth Mycological Institute, Ferrylane, Kew Survey, UK, pp.663.

Andersen, B., Kroger, E., Roberts, R.G., 2001. Chemical and morphological segregation of Alternaria alternata, Alternaria gaisen and Alternaria longipes. Mycological Research 105: 291-299.

Ayyanagar, C.R., 1928. A leaf spot and blight Disease of onions caused by Alternaria palandui. Nov. Agric. Res. Inst. Pusa Bull 179:141-179.

Babu, S., Seetharaman, K., Nandakumar, R., Johnson, I., 2000. Variability in cultural characteristics of tomato early blight pathogen. Plant Disease Research 15: 121.

Chowdappa, P., Sandhya, Bhargavi, B.R., 2012. Diversity analysis of Alternaria porri (Ellis) Cif - causal organism of purple leaf blotch of onion. International Journal of Innovative Horticulture 1(1):11-17.

Cramer, C.S., 2000. Breeding and genetics of Fusarium basal rot resistance in onion. Euphytica 115: 159-166.

Elliott, J.A., 1917. Taxonomic characters of the genera Alternaria and Macrosporium. American Journal of Botany 4: 439476.Ellis MB. 1971. Dematious Hyphomycetes. Common Wealth Mycological Institute, Kew Surrey, England. 132-137.

Ellis, M.B., 1971. Dematious Hyphomycetes. Common Wealth Mycological Institute, Kew Surrey, England.

Fernandez, J., Rivera-Vargas, L.I., 2007. Alternaria spp. occurring in onion foliage: Morphology, Pathogenicity and DNA analysis. Proceedings of the Annual Meeting of the Puerto Rican Society of Agricultural Sciences (SOPCA), Catano.

Gardes, M., Bruns, T.D., 1993. ITS primers with enhanced specificity for basidiomycetes - application to the identification of mycorrhizae and rusts. Molecular Ecology 2: 113-118.

Gardes, M., White, T.J., Fortin, J.A., Bruns, T.D., Taylor, J.W., 1991. Identification of indigenous and introduced symbiotic fungi in ectomycorrhizae by amplification of nuclear and mitochondrial ribosomal DNA. Canadian Journal of Botany 69:180-190.

Goyal, P., Chahar, M., Hahar, A.P., Mathur, A., Kumar, Chattopadhyay, C., 2011. Morphological and cultural variation in different oilseed Brassica isolates of Alternaria brassicae from different geographical regions of India. Indian Journal of Agricultural Sciences 81(11): 1052-58.

Gupta, R.B.L., Pathak, V.N., 1998. Yield loss in onion due to purple blotch disease caused by Alternaria porri. Phytophylactica 20:21-23

Gupta, R.P., Srivastava, V.K., Pandey, V.B., 1986. Control of Purple blotch disease of onion seed crop. Indian Phtopathology39:303-307.

Kadam, B.P., Chavhan, R.L., Chakrabarty, P.K., Patil, F.S., 2009. Characterization of variability in some pathogenic species of Alternaria based on the nucleotide sequence of ribosomal DNA. Journal of Plant Biochemistry and Biotechnology 18(1):59-64

Kannan, R., 1992. Studies on leaf blight of onion (Allium cepa L.) caused by Alternaria alternata (Fr.) keissler. M.Sc. Thesis, Tamil Nadu Agricultural University, Coimbatore, India.

Karlatti, R.S., 1983. Studies on leaf and inflorescence blight of marigold (Tagetes erecta Linn.) caused by Alternariazinniae, M.B. Ellis. M.Sc. (Agri.) Thesis, University of Agricultural Sciences, Bangalore. pp. 104.

Karthikeyan, M., 1999. Studies on onion (Allium cepa var. Aggre gatum L.) leaf blight caused by Alternaria palandui ayyangar. M.Sc. Thesis, Tamil Nadu Agricultural University, Coimbatore. India.

Kaul, A.K., Saxena, H.K., 1988. Physiological specialization in Alternaria solani causing early blight of potato. Indian Journal of 
mycology and Plant Pathology 18(2): 128-132.

Kaur, S., Singh, G., Banga, S.S., 2007. Documenting variation in Alternaria brassicae isolates based on conidial morphology, fungicidal sensitivity and molecular profile. (in) Proceeding of the 12th International Rapeseed Congress, 26-30 March, Wuhan, China 4: 87-89.

Kusaba, M., Tsuge, T., 1995. Phylogeny of Alternaria fungi known to produce hostspecific toxins on the basis of variation in internal transcribed spacers of ribosomal DNA. Current Genetics 28:491-498.

Lakra, B.S., 1999. Development of purple blotch incited by A.porri and its losses in seed crop of onion (Allium cepa). Indian Journal of Agricultural sciences 69:145Peever T.L., Su G., Carpenter-Boggs L., Timmer L.W., 2004. Molecular systematics of citrus-associated Alternaria species. Mycologia 96: 119134.

Martin, K.J., Rygiewicz, P.T., 2005. Fungalspecific PCR primers developed for analysis of the ITS region of environmental DNA extracts. BMC Microbiology 5:28.

Meena, P.D., Chattopadhyay, C., Kumar, V.R., Meena, R.L., Rana, U.S., 2005. Spore behaviour in atmosphere and trends in variability of Alternaria brassicae population. Indian Journal of Mycology and Plant Pathology 35: 511.

Meena, P.D., Rani, A., Meena, R., Sharma, P., Gupta, R., Chowdappa, P., 2012. Aggressiveness, diversity and distribution of Alternaria brassicae isolates infecting oilseed Brassica in India. African Journal of Microbiology Research, 6:24: 52495258.

Mohan, K., 1996. Management of onion (Allium cepa L.) leaf blight disease incited by Alternaria palandui ayyangar with special reference to biological control. M.Sc. Thesis, Tamil Nadu Agricultural University, Coimbatore, India.

Naik, M.K., Prasad, K.V., Bhat, K.V., Devika Rani, 2010a. Morphological, physiological, pathogenic and molecular variability among isolates of Aletrnaria solani from tomato. Indian Phytopathology 63(2):168-173.

Neergaard, P., 1945. Danish Species of Alternaria and Stemphylium. Oxford University Press, London.

Nolla, J.A.B., 1927. A new Alternaria Disease of onions (Allium cepa). Phytopathology 17: 115-137.

Osiru M. 2008. Distribution, variability and pathogenicity of Alternaria leaf petiole and stem blight disease of sweet potato in Uganda. PhD. Thesis. Makerere University, Kampala. Pp 33-61.

Peay, K.G., Kennedy, P.G., Bruns, T.D., 2008. Fungal community ecology a hybrid beast with a molecular master.BioScience58: 799-810.

Peever, T.L., Su, G., Carpenter-Boggs, L., Timmer, L.W., 2004. Molecular systematics of citrus-associated Alternaria species. Mycologia 96: 119134.

Perez, S., Martinez, B., 1996. Selection and characterization of Alternaria solani Sor. isolates of tomato. Revista de Proteccion Vegetable. 10(2):163-167.

Ponnappa, K.M., 1974. Leaf blight of onion (Allium cepa) caused by Alternaria cepulae Ponnappa and Deshpande. BlihefteZur Nova Hadwigia 47: 547-564.

Prasad, M.S., Sujatha, M., Rao, S.C., 2009. Analysis of Cultural and Genetic Diversity in Alternaria helianthi and Determination of Pathogenic Variability Using Wild Helianthus Species. Journal of Phytopathology 157(10):585-648.

Prasad, Y., 2002. Studies on variability, pre and post-harvest management of early blight (Alternaria solani) (EII and Martin) Jones and Grout) of tomato. M.Sc. (Agri.) Thesis, University of Agricultural Sciences, Dharwad, p. 1-150.

Pryor, B.M., Michailides, T.J., 2002. Morphological, pathogenic and molecular characterization of Alternaria isolates associated with Alternaria late blight of Pistachio. Phytopathology 92:406-416. 
Raeder, U., Broda, P., 1985. Rapid preparation of DNA from filamentous fungi. Letters in Applied Microbiology 1: 17-20.

Ramjegathesh, R., Ebenezar, E.G., Muthusamy, M., 2011.Management of onion leaf blight by Alternaria alternata (FR.) Keissler by botanicals and bio-control agents. Plant Pathology Journal 10(4):192-196.

Ramjegathesh, R., Ebenezar, E.G., 2012. Morphological and Physiological Characters of Alternaria alternata Causing Leaf Blight Disease of Onion. International Journal of Plant Pathology 3: 34-44.

Rotem, J., 1994. The genus Alternaria: Biology, epidemiology and pathogenicity. APS Press, St. Paul, Minnesota.

Savitha, A.S., 2004. Variability and toxin studies of Alternaria spp., the incident of blight of sesame. M.Sc. (Agri.) Thesis, University of Agricultural Sciences, Dharwad, India.

Simmons, E.G., 1967. Typification of Alternaria, Stemphylium, and Ulocladium. Mycologia 59:67-92.

Simmons, E.G., 1992. Alternaria taxonomy: current status, viewpoint, challenge. In: Chelkowski J, Visconti A, eds. Alternaria biology, plant diseases and metabolites. Amsterdam: Elsevier Science Publishers, Amsterdam.

Singh, D., Singh, R., Singh, H., Yadav, R.C., Yadav, N., Barbetti, M., Salisbury, P.,
Nimbal, S., Chattopadhyay, C., Kumar, A., 2007. Cultural and morphological variability in Alternaria brassicae isolates of Indian mustard (Brassica juncea L. Czern and Coss.). (in) Proceeding of the 12th International Rapeseed Congress, 26-30 March, Wuhan, China 4: 158-160.

Tripathi, M.K., Tiwari, S., Khare, U.K., 2008. In vitro selection for resistance against purple blotch disease of onion (Allium cepa L.) caused by Alternaria porri. Biotechnology 7: 80-86.

Tuite J. 1969. Plant pathological methods; fungi and bacteria. Burgess Publishing Co. Minneapolis, USA. pp. 1-238

Varma, K.P., Sher, Singh, Gandhi, S.K., 2007. Variability among Alternaria solani isolates causing early blight of tomato. Indian Phytopathology 60(2):180-186.

White, T.J., Brun, T., Lee, S., Taylor, J., 1990. Amplification and direct sequencing of fungal ribosomal RNA genes for phylogenetics, In: PCR Protocols. A guide to methods and applications. (M.A. Innis, D.H. Gelfand, J.J. Sninsky, T.J. White, eds.), Academic Press, San Diego, USA. 315-320.

Wiltshire, S.P., 1933. The foundation species of Alternaria and Macrosporium. Transactions of the British Mycological Society 18: 135-160.

Wiltshire, S.P., 1947. Species of Alternaria on brassicae. Mycologia 20:1 - 15.

\section{How to cite this article:}

Chethana, B.S., Girija Ganeshan, Archana S. Rao and Bellishree, K. 2018. Morphological and Molecular Characterization of Alternaria Isolates Causing Purple Blotch Disease of Onion. Int.J.Curr.Microbiol.App.Sci. 7(04): 3478-3493. doi: https://doi.org/10.20546/ijcmas.2018.704.394 